\title{
NICZYJE CZY WSPÓLNE? O NATURALNYCH I SZTUCZNYCH JĘZYKACH MIESZANYCH
}

\author{
Słowa kluczowe: języki mieszane, sztuczne, naturalne, interjęzyk, lingua franca
}

Streszczenie. Celem tekstu jest uporządkowanie i scharakteryzowanie naturalnych i sztucznych języków mieszanych, które podlegają również klasyfikacji „edukacyjnej”. W artykule zwraca się uwagę na to, że naturalne języki mieszane (np. pidgin) nie były poznawane w szkole, zaś sztuczne (np. volapük) można opanować tylko w wyniku uczenia się/nauczania. Omówiono interjęzyk jako zjawisko obecne w procesie dydaktycznym, ale i poza nim - jako efekt naturalnego kontaktu języków. Refleksji poddano kwestię poszukiwań języka uniwersalnego, który służyłby do globalnego porozumiewania się i podjęto próbę wyjaśnienia istoty lingua franca, akcentując rolę angielszczyzny (także jej odmian Basic English i Plain English) we współczesnym świecie.

\section{WSTĘP}

Języki są różnie kategoryzowane, np. w zależności od liczby i wielkości populacji, które się nimi posługują, sytuacji geopolitycznej, miejsca użytkowania, statusu, żywotności, funkcji pełnionych w danym społeczeństwie, stopnia trudności, od tego, czy posiadają pismo itd. W niniejszym tekście refleksji poddane zostały naturalne i sztuczne języki mieszane, które pogrupowano i szkicowo scharakteryzowano. W encyklopediach i w słownikach (polskich i zagranicznych) trudno o jasne odpowiedzi na pytania dotyczące tych pojęć. Niektóre definicje „są nieprecyzyjne, przez co czytelnik, który nie orientuje się w problematyce i styka się z nimi po raz pierwszy, może zrozumieć, że są one niemal synonimiczne" (Hlibowicka-Węglarz 2017, s. 26). Wśród badaczy nie ma pełnej zgodności w nazywaniu ani określeniu takich kodów, dlatego pewne uporządkowanie, nawet rudymentarne, wydaje się konieczne. Podniesiono tu także kwestię poszukiwań języka uniwersalnego (międzynarodowego), który by służył do globalnego porozumiewania się.

*ewa.lipinska@uj.edu.pl, Uniwersytet Jagielloński, Wydział Polonistyki, Katedra Języka Polskiego jako Obcego, ul. Grodzka 64, 31-044 Kraków. 
Na początku przywołamy potrzebne w dalszej części terminy (zob. Encyklopedia językoznawstwa ..., 1999): język mieszany, naturalny, sztuczny, uniwersalny.

- Język mieszany powstaje wskutek długich i bliskich kontaktów dwu lub więcej grup etnicznych, a zatem i ich języków, które splatają się ze sobą (zob. Encyklopedia językoznawstwa ..., 1999, s. 271). Jego wyróżnikiem jest to, że nie daje się zaklasyfikować do żadnej rodziny ${ }^{1}$.

- Język naturalny - kod powstały na drodze rozwoju historycznego, zróżnicowany geograficznie i społecznie (zob. Encyklopedia językoznawstwa..., 1999, s. 272). Zrodził się z naturalnej potrzeby komunikacyjnej i służy do porozumiewania się ludzi w obrębie danej grupy (np. język polski, czeski, niemiecki) (zob. Płóciennik, Podlawska 2008, s. 53). Ewoluuje wraz człowiekiem/grupą etniczną.

- Język sztuczny - język pomocniczy utworzony w celu porozumiewania się w określonej dziedzinie naukowo-technicznej lub komunikacji międzynarodowej (Encyklopedia językoznawstwa..., 1999, s. 273). Kod taki został wymyślony przez konkretne osoby w wyniku ,utopijnej idei powrotu do stanu sprzed budowy wieży Babel, gdy ludzkość posługiwała się jednym językiem" (Łuczyński, Maćkiewicz 2002, s. 109). W zamierzeniu miał stanowić uniwersalny system komunikacji.

- Język międzynarodowy² nie ma odniesienia do konkretnej narodowości. To „taki język naturalny lub sztuczny, którym posługują się różne plemiona lub narody w kontaktach wzajemnych, głównie naukowych, handlowych i dyplomatycznych" (Encyklopedia językoznawstwa..., 1999, s. 271). Stanowi też zazwyczaj język urzędowy w organizacjach międzynarodowych albo w kilku państwach i/ lub taki kod, który opanował świat. W tabeli 1 wymieniono języki, które na przestrzeni dziejów zyskiwały rangę międzynarodową.

Tabela 1. Języki uważane za międzynarodowe

\begin{tabular}{|c|c|}
\hline \multicolumn{2}{|c|}{ Języki międzynarodowe } \\
\hline naturalne & sztuczne (pomocnicze) \\
\hline $\begin{array}{c}\text { greka, łacina, włoski, francuski, angielski, } \\
\text { niemiecki, hiszpański, rosyjski, arabski, } \\
\text { chiński, perski, indonezyjski, hausa suahili }\end{array}$ & $\begin{array}{c}\text { esperanto, volapük, occidental, novial, ido, } \\
\text { interlingua }\end{array}$ \\
\hline
\end{tabular}

Źródło: opracowanie własne na podstawie Encyklopedia językoznawstwa... 1999, s. 271

${ }^{1}$ Za początek naukowego podejścia do badań nad językami mieszanymi uznaje się publikacje austriackiego romanisty i indoeuropeisty Hugona Schuchardta. W dobie narodzin tzw. geografii lingwistycznej jako jeden z pierwszych zainteresował się problemami kontaktów językowych, wielojęzyczności, a także wszelkich uwarunkowań, które prowadzą do mieszania się języków (Hlibowicka-Węglarz 2017, s. 25-26).

${ }^{2}$ Oficjalnie rangę międzynarodową ma sześć języków używanych w ONZ: angielski, francuski, hiszpański, rosyjski, chiński i arabski (Encyklopedia językoznawstwa ..., 1999, s. 271). 


\title{
2. NATURALNE JEZZYKI MIESZANE W KONTEKŚCIE POZAEDUKACYJNYM
}

Przykładem języków składających się z elementów innych (różnych) kodów są pidginy ${ }^{3}$, sabiry i języki kreolskie. Wliczymy tu także lingua franca oraz interjęzyk - kody naturalne z punktu widzenia ich rozwoju, niemające jednak umocowania w kulturze, co odróżnia je od innych, „normalnych” języków naturalnych. Używane w zakresie komunikacji słuchowo-ustnej, istnieją tylko w pewnych strefach geograficznych, mają określony zasięg, a żywot niektórych jest ograniczony w czasie.

\subsection{PIDGINY}

Pidginy są prostymi językami wehikularnymi, wspierającymi lub umożliwiającymi komunikację (wyłącznie ustną) osób lub grup społecznych, które na co dzień używają odmiennych (różnych) kodów, a więc wzajemnie niezrozumiałych dla rozmówców. Zdecydowana większość pidginów uformowała się w dobie wielkich ekspansji zamorskich (na szlakach handlowych, na plantacjach, w fortach) ze względu na wyjątkowo sprzyjający kontekst społeczny, tj. wielokulturowość i wielojęzyczność (zob. Hlibowicka-Węglarz 2017, s. 27). Powodował on jednak pewien „komunikacyjny pośpiech”:

\begin{abstract}
Właśnie w takiej sytuacji tworzy się spontaniczna forma językowa oparta na znacznych uproszczeniach zarówno słownictwa, jak i struktur gramatycznych języka grupy dominującej. Formie tej często towarzyszą indywidualne środki wyrazu, zależne od inwencji językowej poszczególnych członków danej społeczności, a także różne formy zastępcze, takie jak język gestów, mimika i wiele innych.
\end{abstract}

(Pereira 2006, za: Hlibowicka-Weglarz 2017, s. 31)

Najbardziej znanym i przytaczanym jako przykład w literaturze przedmiotu jest pidgin, który uformował się w okresie pierwszych kontaktów ludności angielskiej z chińską ${ }^{4}$ rozpowszechniony w Azji Wschodniej i Oceanii.

Dwa główne wyznaczniki pidginów, to (zob. Klein 1989, s. 47; Warchoł-Schlottmann 1994, s. 33):

1. sposób powstania i używania. Pidginy służą dokładnie określonym, ograniczonym komunikacyjnym celom. Zmniejszają, a w szczególnych

${ }^{3}$ Obok zapisu pidgin (stosowanego w niniejszym tekście), używa się też formy pidżyn lub pidżin. O pidginach i kreolach zob. też: Hamers, Blanc (1983), Szulc (1994), Encyklopedia językoznawstwa ..., (1999), Łuczyński, Maćkiewicz (2002), Lipińska (2003), Hornsby (2016).

${ }^{4}$ Nazwa tego kodu najprawdopodobniej wywodzi się z fonetycznego zniekształcenia angielskiego słowa business przez Chińczyków (zob. Encyklopedia językoznawstwa ..., 1999, s. 432). 
warunkach stabilizują, ekstremalny dystans socjalny, np. między kolonialistami a ludnością miejscową;

2. ich struktura. Wykazują cechy obydwu języków wchodzących w kontakt, ale również takie, których nie posiada żaden z nich. Typowe znamiona strukturalne: brak rozróżnienia rodzajów gramatycznych, wyrażanie stosunków czasowych, aspektowych i modalnych przez partykuły adwerbialne zamiast przez fleksję czasownika, użycie czasowników w formie bezokolicznikowej, przewaga zdań pojedynczych oraz ograniczony, ubogi słownik.

W odniesieniu do punktu pierwszego uściślijmy, że aby narodził się pidgin, musi dojść do kontaktu między językami niezrozumiałymi dla uczestników aktu komunikacji; musi także wystąpić silna potrzeba porozumienia się i wzajemnego zrozumienia podczas przejściowej lub ograniczonej komunikacji. Tubylcy na ogół wyłapywali kilka słów od przybyszów, którymi najczęściej byli kolonizatorzy, próbując się z nimi komunikować, a ci odpowiadali im w podobny sposób, utwierdzając ich w przekonaniu, że mówią w obcym języku ${ }^{5}$. Sami dodawali też elementy języka miejscowego i w ten sposób powstawał kod, który nie był pierwszym/ojczystym żadnej ze stron, a więc nie miał rodzimych użytkowników.

Istotnym wyróżnikiem pidginów jest d w u s tro n n o ść (bilateralność) ich używania, posługuje się nimi bowiem grupa dominująca i zdominowana, a czasem osoby będące w tej samej sytuacji, o jednakowym statusie społeczno-politycznym, np. niewolnicy z różnych plemion mówiący różnymi narzeczami (zob. Hamers, Blanc 1983, s. 255). Dwustronność ta zakłada, że

aby móc uznać jakąś formę komunikacji za pidgin, powinny się nią posługiwać obie strony użytkowników pozostające w kontakcie. Jeśli dana forma językowa jest używana jedynie przez jedną z nich, mamy do czynienia z pseudopidżynem lub pseudosabirem [wyróżn. E.L.].

(Perego 1968, za: Hlibowicka-Węglarz 2013, s. 25)

Do punktu drugiego, dotyczącego struktury, dodajmy, że Hamers i Blanc (1983) za cechy charakterystyczne pidginów uznali: symplifikację formy zewnętrznej, która może prowadzić do homofonii, redukcję funkcji i dziedzin użycia oraz redukcję formy wewnętrznej, polegającą na zawężeniu części mowy do rzeczownika i czasownika z dodatkiem kilku przymiotników i przysłówków, braku strony biernej oraz rozróżnienia rodzajów, liczb i czasów ${ }^{6}$.

${ }^{5}$ W kwestii kontaktu dwu języków i wzajemnego ich oddziaływania na siebie Ochotna (2016, za: McArthur 1992, s. 270) wprowadza określenie język superstratowy i substratowy. Ten pierwszy, jako język dominujący, stanowi podstawę tworzenia się pidginu, drugi zaś jest jego swoistym dopełnieniem.

${ }^{6}$ Zob. też Ochotna (2016), Hlibowicka-Węglarz (2017). 
Warto mieć też na uwadze, że chociaż pidginy to mocno uproszczone języki, są kompletne. Kody te mogą ewoluować z fazy nieustabilizowanej do ustabilizowanej $^{7}$, a także stopniowo się rozprzestrzeniać. Są potencjalnymi językami prekreolskimi (zob. Hlibowicka-Węglarz 2013 [wyróżn. E.L.]).

\subsection{SABIRY}

Sabiry ${ }^{8}$ to również języki mieszane powstałe w efekcie kontaktu dwóch lub więcej kodów. Ich system jest bardzo prosty - sprowadza się do zaledwie kilku reguł i ich kombinacji; słownictwo mają ubogie i zredukowane do określonej dziedziny semantycznej, prawie zawsze dotyczącej handlu.

W sumie sabir to rodzaj pidginu, ale mniej kompletny. O ile jednak mianem tego drugiego określa się/powinno się określać rodzaj języka mieszanego, o tyle ten pierwszy - zdaniem Hlibowickiej-Węglarz (2017) - funkcjonuje (nie całkiem słusznie) jako nazwa własna9. Przez niektórych badaczy jest uważany za kod będący etapem ewolucji śródziemnomorskiej lingua franca (zob. poniżej), co zresztą miało zapoczątkować jej schyłek. Sabir stał się następnie podstawą innej formy językowej, zwanej ,żydowskim sabirem” (Żydzi, którzy ze względu na prowadzoną działalność handlową mieli olbrzymi wpływ na życie w tym regionie, porozumiewali się między sobą w języku arabskim, nieco zmodyfikowanym fonetycznie i leksykalnie, co przypominało Francuzom specyficzną odmianę sabi$r u$ ). Właśnie ta forma uznawana jest za jedną z ostatnich form sabiru i jednocześnie za schyłkowe stadium istnienia śródziemnomorskiej odmiany lingua franca (zob. Hlibowicka-Węglarz 2017, s. 38).

Sabir - przeciwnie niż pidgin - jest używany do komunikacji jednostronnej (unilateralnej), ponieważ tylko jedna grupa stara się reprodukować język drugiej grupy (zob. Hamers, Blanc 1983).

\footnotetext{
${ }^{7}$ Boutet (1997, s. 23) nazywa pidgin ,językiem d ru gi m ustabilizowanym” [wyróżn. E.L.].

${ }^{8}$ Nazwa najprawdopodobniej pochodzi od saber (hiszp.) - 'wiedzieć'. Kod ten rozwijał się przede wszystkim w portach. Bardzo podobny jest też język bêche-de-mer. Zob. np. Encyklopedia językoznawstwa..., (1999, s. 74).

${ }^{9}$ Sabir kojarzy się z językiem o silnych wpływach francuskich, co wynika z faktu najazdu, podbicia i kolonizacji Algieru przez Francję w 1830 r. Według tej teorii, to właśnie Francuzi nadali ówcześnie używanemu językowi w Algierze nazwę sabir lub petit mauresque. Informacji na temat tego języka należy szukać przede wszystkim w pracach autorów francuskich (zob. Hlibowicka-Węglarz 2017, s. 38).
} 


\subsection{JĘZYKI KREOLSKIE}

Języki kreolskie to ustabilizowane języki naturalne, które powstały z wymieszania się kodów źródłowych (zob. Hornsby 2016). Powstają przez morfologiczną symplifikację któregoś z języków kolonizatorów (głównie angielskiego, francuskiego, hiszpańskiego, portugalskiego, holenderskiego) i przesycenie go elementami leksykalnymi języków tubylców. Chodzi więc o językową zależność grupy zdominowanej, analfabetycznej, od grupy dominującej. Języki kreolskie formują się głównie na wyspach (zwłaszcza uprzednio niezamieszkałych), nie na kontynencie.

Uważa się, że wyspy implikują swego rodzaju odcięcie lub też izolację ich mieszkańców zarówno od rodzimych kultur, jak i od rdzennych języków. Jednocześnie sprzyjają one najróżniejszym typom kontaktów, a także kulturowemu mieszaniu się członków tworzącej się społeczności. Zarówno to odcięcie, jak i proces mieszania się kultur i ras prowadzą do sytuacji, w której języki rodzime przestają być funkcjonalne, następuje zjawisko tzw. kryzysu językowego, w wyniku czego niezwykle szybko pojawiają się różne formy języków mieszanych.

(Hlibowicka-Węglarz 2016, s. 172)

Wskutek nowych funkcji socjalnych pidgin zmienia się przez kilka pokoleń aż wreszcie przeobraża się w rodzimy język danej wspólnoty i następuje wtedy „kreolizacja” (zob. Boutet 1997) ${ }^{10}$.

Wiele języków kreolskich rozwijało się z pidżynów, jednakże różnią się od nich tym, że dla dzieci (w) posługującej się kreolem ${ }^{11}$ społeczności jest on językiem pierwszym, przez co nabywa cech języka naturalnego, których zazwyczaj brak pidżynom.

(Hornsby 2016, s. 83)

Proces kreolizacji może odbywać się zarówno stopniowo, jak i mieć gwałtowny przebieg; może też wystąpić w dowolnym momencie podczas zmian zachodzących w wykształconym języku (zob. McArthur 1992, s. 271, za: Ochotna 2016, s. 87). W językoznawstwie wprowadzono również termin „dekreolizacja”, który „określa proces polegający na dominacji creole nad językiem, który stał na pozycji superstratowej (...). Proces ten zachodzi podczas ponownego kontaktu creole z językiem, który stanowi jego podstawę (np. angielski w English based creoles)" (ibid.).

${ }^{10}$ Zob. szerzej: Hamers, Blanc (1983); Encyklopedia językoznawstwa ..., (1999, s. 275), Lipińska (2003).

${ }^{11}$ Mianem „kreole” (,creole”) pierwotnie określano osoby urodzone „,w jednym miejscu, ale zmuszone do zmiany miejsca zamieszkania, np. niewolnicy lub potomkowie cudzoziemców osiedlających się na danym terenie, np. potomkowie niewolników afrykańskich lub białych osadników w Indiach" (zob. McArthur 1992, s. 270, za: Ochotna 2016, s. 87). Dopiero w XIX w. uznano, że nazwę tę można stosować także do opisywania języka. 
Oprócz kreolizacji językowej istnieje też kreolizacja kulturowa w postaci muzycznej, kulinarnej, religijnej, literackiej i medycznej (Chaudenson 1989, 1992, za: Hlibowicka-Węglarz 2013, s. 62). Może ona zaistnieć wtedy, gdy jest reprezentowana przez język naturalny, żywy i rozwijający się.

Zaznaczmy, że języki kreolskie nie są hybrydami - wręcz przeciwnie, są w pełni rozwinięte, choć niektóre nie zostały skodyfikowane (zob. Hamers, Blanc 1983, s. 259).

\subsection{LINGUA FRANCA}

Do języków mieszanych należy zaliczyć także lingua franca (LF). McArthur wyróżnił dwie postaci tego kodu:

1. język przyjęty przez daną grupę (G1) i używany przez nią w celach porozumiewania się z inną grupą (G2); dla G1 jest to język obcy, dla G2 - rodzimy (np. współcześnie wszechobecny angielski);

2. kod powstały z połączenia dwu języków używanych w celach komunikacyjnych i nazywanych pidginem lub creolem w zależności od stopnia rozwoju (na podst. McArthur, 1992, s. 606, za: Ochotna 2016, s. 87).

Pierwsza postać tak określonej 'lingua franca' zostanie omówiona w dalszej części tekstu (zob. p. 4). Tu przyjrzymy się jej drugiej formie, lecz najpierw uściślijmy, że może się ona odnosić do swoistej kompilacji dwu lub więcej języków. Przykładem jest najbardziej znana lingua franca (czyli ‘język Franków’), którą posługiwano się w portach śródziemnomorskich jeszcze w XX wieku, a obecnie jest już językiem martwym. Kod ten składał się z elementów języków: włoskiego, hiszpańskiego, francuskiego, arabskiego - z przewagą dwóch pierwszych (zob. Encyklopedia językoznawstwa ..., 1999). Służył głównie do celów handlowych i dyplomatycznych. Jego zasięg był spory, gdyż obejmował basen Morza Śródziemnego. Mylnie określano go językiem kreolskim, chociaż nie był on językiem rodzimym dla żadnej grupy użytkowników, nigdy bowiem nie istniało społeczeństwo, które by się posługiwało LF tak, jak językiem ojczystym.

Ze względu na rolę społeczną kod ten przypomina pidgin lub sabir, gdyż służył za środek porozumiewania się $\mathrm{w}$ środowiskach wielokulturowych i wielojęzycznych na danym terytorium. Podobnie jak pidgin, a inaczej niż sabir - był środkiem komunikacji dwustronnej. Różnica między tymi terminami jest jednak zasadnicza, bowiem definicja lingua franca nie uwzględnia ani struktury, ani sposobu kształtowania się tego kodu, ograniczając się jedynie do jego funkcji (zob. Hlibowicka-Węglarz 2017, s. 34). W istocie rzeczy LF może więc stać się każdy język: naturalny, pidginowy, kreolski, sztuczny, gdyż wszystkie one są w stanie pełnić funkcję kodu wspólnego w wyżej określonych okolicznościach. 
Trzeba także mieć świadomość, że nazwy języków, o których powyżej mowa powinny być używane w znaczeniu proprialnym, a nie apelatywnym. Zdaniem Hlibowickiej-Węglarz (2017) jest to jedna z przyczyn niejasności ich definicji oraz kontekstu ich używania.

\subsection{INTERJĘZYK}

Z odmianami mieszanymi języków naturalnych kojarzy się tak samo pojęcie interjęzyka (interlanguage ${ }^{12}$, którego autorem jest Selinker (1972). Interjęzyk w terminologii polskiej występuje czasem pod nazwą języka pośredniego (Szulc 1994, s. 100). Nie jest to w pełnym tego słowa znaczeniu kod naturalny, ale nie jest on również językiem sztucznym. „Tworzy się” sam, bez udziału naukowców, nie ma jednak historycznej ciągłości ani nie stoi za nim żadne tło kulturowe. Należy wyróżnić dwie jego odmiany - dydaktyczną i naturalną (pozadydaktyczną).

\subsubsection{Interjęzyk w glottodydaktyce}

Selinker zwrócił uwagę na to, że „osoba ucząca się języka obcego (...) wykorzystuje reguły swojego języka ojczystego i kompilując je z poznawanymi regułami języka drugiego [docelowego, przyp. E.L.] przekształca je w zupełnie odrębny, abstrakcyjny, ale funkcjonalny system gramatyczny" (Borecka 2017, s. 14). Nie chodzi tu jednak tylko o gramatykę, ale także inne aspekty językowe - zwłaszcza słownictwo i wymowę. Termin interjęzyk odnosi się więc do kompetencji przejściowej między językiem wyjściowym (j.w.) a docelowym (j.d.), przy czym dopełnia ją idiolekt każdego użytkownika ${ }^{13}$, co powoduje, że interjęzyk jest kodem jednostkowym. Przykładowo - inaczej ukształtuje się on u uczącego się języka hiszpańskiego inżyniera z Zamościa, a inaczej u nauczycielki z Zakopanego czy ekonomisty z Bytomia i lekarza z Pucka - osób, dla których językiem wyjściowym powinien być standardowy polski, ale w rzeczywistości ma on charakter idiolektalny (zob. Lipińska, w druku). Ujawnia on bowiem nie tylko pochodzenie regionalne czy wykształcenie/ zawód, lecz także osobnicze cechy językowe

${ }^{12}$ Nazywany jest też dialektem idiosynkratycznym / systemem aproksymatywnym. Zob. szerzej m.in. Komorowska (1980); Hamers, Blanc (1983); Deprez (1994); Lipińska (2003); Arabski (2007); Żurek (2014).

${ }^{13}$ Ujawnia on pochodzenie regionalne i społeczne użytkownika, jego wykształcenie, wiek, zawód, tradycje rodzinne, opanowanie danej normy językowej, a także umiejętność posługiwania się odmianami stylistycznymi (zob. Płóciennik, Podlawska 2008, s. 154). 
(jak np.: swoistą składnię, intonację, leksykę). Mimo to uczestnicy kursu stanowią grupę jednorodną językowo - w tym przypadku Polaków uczących się hiszpańskiego. Ich 'kompetencja przejściowa', oscylująca między polszczyzną a hiszpańszczyzną, służy komunikacji uczniów z nauczycielem. Układa się ona na linii j.w. $\rightarrow$ j.d., a jej otoczkę stanowi idiolekt każdego użytkownika. Jeśli zaś grupa ucząca się hiszpańskiego jest wielonarodowa, schemat jest podobny, jednak słuchacze mają kontakt z różnymi kodami wyjściowymi uczestników kursu i ich idiolektami, które wpływają na siebie wzajemnie. W tym przypadku więc powstają bardziej złożone kody przejściowe, które można nazwać j ęzy ka mi pośrednic zacy$m i$ w komunikacji uczących się j.d. Muszą się oni bowiem dogadywać między sobą i z nauczycielem. Tak rozumiane warianty interjęzyka pojawiają się częściej w początkowej fazie procesu opanowywania języka obcego i charakteryzuje je niepoprawność. Są postrzegane jako kody, w których dopuszczalne i akceptowalne jest popełnianie błędów przez uczącego się w drodze do osiągniecia wyższego stopnia zaawansowania, jeżeli widzimy to jako „ciąg przejść od jednego wariantu do następnego, od jednego stopnia do następnego, a każde następne przejście zbliża się do normy języka docelowego" (Warchoł-Schlottmann 1994, s. 32).

Czasem jednak pojawia się tendencja do pewnego zastoju rozwojowego i utrzymywania nieprawidłowych cech owego kodu, które nie ustępują po objaśnieniach nauczyciela ani po specjalnych ćwiczeniach (zob. Komorowska 1980; Borecka 2017). Mówi się wtedy o zamrożeniu kompetencji (fosylizacji ${ }^{14}$ ). Termin został wprowadzony również przez Selinkera (1972) na określenie sytuacji, kiedy uczący się języka docelowego osiąga wystarczający poziom jego znajomości, by funkcjonować w danej społeczności, mimo sprzyjających warunków nie posuwa się jednak w językowym rozwoju ${ }^{15}$.

Interjęzyk jest powiązany z transferem, czyli skłonnością do przenoszenia uprzednio przyswojonych nawyków językowych na nowo opanowywany materiał w innym języku. W tym sensie interjęzyk jest wymownym przykładem transferu negatywnego (interferencji) ${ }^{16}$, który skutkuje powstawaniem błędów. Dodajmy, że interjęzyk może przypominać fragmentaryczne przełaczenie kodów $w^{17}$, czyli ich mieszanie (mélange de codes, code mixing). Wszystko to pokazuje, że omówione pokrótce pojęcie jest złożone i wieloznaczne (zob. diagram 1).

${ }^{14}$ Zob. Arabski (1985, s. 70-71), Grosjean (1982, s. 94-295), Warchoł-Schlottmann (1994, s. 46), Lipińska (2003, s. 93), Żurek (2014, s. 294), Borecka (2017).

${ }^{15}$ Odróżnia się fosylizację tymczasowa od permanentnej, a także całościowa od częściowej (zob. Lipińska 2003, Borecka 2017).

${ }^{16}$ Zdaniem Arabskiego (2007, s. 345-346) na transfer negatywny składają się: „niedostateczna produkcja”, „nadprodukcja”, „błędy produkcji”, „kalki”, „hiperpoprawność”, „błędna interpretacja”. Zob. też Komorowska (1980, s. 106-107); Lipińska (2019).

${ }^{17}$ Jest to Alternance de Code d'Incompétence $(A C I)$, która oznacza brak kompetencji dwujęzycznej; przeciwieństwem jest Code Alterne du Bilingue $(C A B)$, będący wyrazem kompetencji bilingwalnej (zob. Hamers, Blanc 1983). Zob. też Warchoł-Schlottmann (1994, s. 193). 
Diagram 1. Zjawiska towarzyszace interjęzykowi (glotto)dydaktycznemu

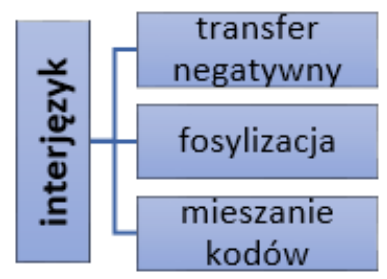

Źródło: opracowanie własne

Interjęzyk w swej (glotto)dydaktycznej postaci ${ }^{18}$ ma więcej wspólnego z terminem nazywającym etap w opanowywaniu języka obcego niż z jakimś konkretnym kodem. Warto więc rozważyć ograniczone jego używanie, gdyż w istocie rzeczy każdy język obcy jest przyswajany i/lub uczony ad infinitum, co oznacza, że w tym procesie wystąpiłaby niezliczona ilość 'etapów', które stanowiłyby ustawiczną 'kompetencje przejściową', bo dążenie do lepszego opanowania języka obcego nigdy się nie kończy.

\subsubsection{Naturalna postać interjęzyka}

Oprócz opanowywania języka obcego w trakcie sterowanego, kontrolowanego i zaplanowanego procesu na kursie czy w szkole, istnieje także naturalny, bezpośredni sposób jego nabycia. Najczęściej ma to miejsce na emigracji, kiedy osoby nowo przybyłe, bez znajomości lokalnego języka, starają się komunikować $\mathrm{z}$ nierodzimym otoczeniem, tj. z sąsiadami, sprzedawcami, kelnerami, obsługą na stacjach benzynowych itd. Przeważnie problem ten dotyczy pracowników fizycznych i/lub nisko wykształconych, nierzadko posługujących się dialektami /gwarami. To, czego uczą się ,ze słuchu”, nakładają na swój sposób mówienia, co, w przypadku polskiego, stanowi zalążek języka polonijnego ${ }^{19}$. O tym, że nawet w obrębie jednej grupy (np. z jednego terytorium) nie jest on jednolity, świadczą chociażby słowniki polonijne, gdzie znajduje się wiele wersji zniekształconych słów i zwrotów pochodzących z języka rdzennych mieszkańców ${ }^{20}$.

${ }^{18}$ Nickel (2000, s. 14) uważa, że jeśli nauczyciele języka obcego nie są native speakerami, sami posługują się interjęzykiem. Mogą oni - podobnie jak uczniowie - stosować strategie symplifikujące, co charakteryzuje język pośredni.

${ }^{19}$ Język polonijny to (w uproszczeniu) melanż elementów języka ogólnopolskiego, cech języka osobniczego oraz języka kraju osiedlenia.

${ }^{20}$ Zob. np. trouble (kłopot/y): trabo, troboł, trubel; garbage (śmietnik, kubeł na śmieci, śmieć): gabeć, garbeć, garbedż, garbidż, garbicz; air conditioning (klimatyzacja, klimatyzator): airkondyszyn, ajerkondyszyn, akordejszyn, erkondyszyn, kondyszyn (Słownik polonijny... 2014). 
Do sytuacji porozumiewania się „Polak vs tubylec” dochodzi także komunikacja „Polak vs nie-Polak/nie-tubylec vs tubylec”. Zdarza się to przeważnie w miejscach pracy, w których spotykają się osoby różnych narodowości, nieznające kodu kraju osiedlenia albo znające go bardzo słabo. Wytwarza się wtedy swoisty język pośredniczący, składający się z kilku interjęzyków. Na przykład, kiedy w warsztacie stolarskim w USA pracuje Polak, Czech, Włoch i Serb, potrafią rozmawiać tak, aby dobrze (wspólnie) wykonać pracę, korzystając również z pozawerbalnych środków: gestykulacji, mimiki, prozodii itp. Kontaktujący się z nimi brygadzista, Amerykanin, modyfikuje swój język, tzn. upraszcza go pod każdym względem, aby się porozumieć z pracownikami. Oni uczą się nie do końca poprawnej postaci angielskiego (przy czym każdy słyszy i wymawia po swojemu), a brygadzista „łapie” ich sposób wyrażania się. Tak naprawdę powstaje wówczas kod o cechach pidginu, który należy do kategorii „naturalne języki mieszane w kontekście pozaedukacyjnym".

Uściślijmy, że tak widziany interjęzyk posiada cechy wspólne z pidginem: jest uproszczony, niepoprawny w konfrontacji z j.d., służy do przekazywania lub uzyskiwania podstawowych informacji. Ponadto obydwa kody łączy fakt, że nie są niczyimi językami rodzimymi. Jednak różni je to, że interjęzyk jest osobniczym kodem użytkownika i - w przeciwieństwie do pidginu - bardzo rzadko stanowi wygodne narzędzie porozumiewania się w obrębie większej grupy. Nie jest więc wspólnym środkiem w komunikacji dwustronnej - każdy interjęzyk bowiem jest inny. W dodatku może występować w piśmie (zob. Deprez 1994, s. 159), a pidgi$n y$ to języki mówione.

\section{SZTUCZNE JĘZYKI MIESZANE W KONTEKŚCIE EDUKACYJNYM}

Mianem języka sztucznego (planowanego) określa się kod, który nie powstał samoistnie na drodze historycznego rozwoju, lecz został stworzony/skonstruowany przez jednostkę lub grupę ludzi dla określonych celów. Może to być język służący do komunikacji na linii człowiek - człowiek (w przypadku braku wspólnego języka), do wymiany informacji w relacji człowiek - komputer albo komputer - komputer (zob. Płóciennik, Podlawska 2008, s. 15; Kulczycki 2011, s. 41, za: Białołus 2018, s. 268). Ze względu na sposób użycia języki sztuczne dzieli się na:

- pomocnicze (auxiliary languages; auxlangs), mające służyć sprawnej komunikacji w wymiarze międzynarodowym (np. esperanto);

- artystyczne (artistic languages; artlangs) powstające jako element świata wyobrażeniowego, np. literackiego, filmowego (np. klingoński w filmie Star Trek); 
- projektowe (engineered languages; engelangs) opracowywane w celach naukowych, do testowania hipotez lingwistycznych itp. (np. toki pona skonstruowany w celu maksymalnego uproszczenia procesu komunikacji i unikania niejednoznaczności) (na podst. Białołus 2018, s. 269).

W niniejszym tekście omawiana jest tylko pierwsza grupa. Kody mieszczące się w niej pretendowały niegdyś do bycia powszechnym, międzynarodowym środkiem komunikacji.

Sztuczne języki pomocnicze składają się z elementów języków naturalnych, tworząc grupę języków aposteriorycznych ${ }^{21}$. Ich cechą charakterystyczną jest to, że „zwykle powstają na papierze, w formie pisanej. Większość z nich w tej formie zostaje i nigdy nie są używane w mowie" (Białołus 2018, s. 173). Zostały wymyślone przez osoby różnych zawodów (zob. tab. 2.), często nieprofesjonalistów hołdujących idei istnienia wspólnego języka ludzkości. Poniżej zamieszczono krótki przegląd najczęściej wymienianych kodów w kolejności alfabetycznej (układ chronologiczny zaprezentowano w tabeli 2):

- adamitik: utworzony ok. 1909 r. przez Węgra Antala Velicsa; za podstawę przyjął język węgierski, którego „nazwa pochodzi z przeświadczenia, że językiem ojczystym pierwszego człowieka, Adama, był język węgierski”; dziś zupełnie nieużywany (zob. Encyklopedia językoznawstwa..., 1999, s. 17);

- esperanto: stworzony ok. 1887 r. przez polskiego lekarza Ludwika Zamenhoffa; opiera się głównie na językach romańskich i częściowo germańskich; charakteryzuje go uproszczona gramatyka, brak wyjątków; istnieje w nim bogata literatura (przekładowa i oryginalna), a patronuje mu Światowy Związek Esperantystów (zob. Encyklopedia językoznawstwa..., 1999, s. 146);

- ido (esperanto reformita): stanowi uproszczoną formę (głównie graficzną i fonetyczną) esperanta; opracowany w latach 1907-1908 we Francji; główny twórca to inżynier Louis de Beaufront oraz dr filozofii Louis Couturat; orędownicy: Jan Niecisław Baudouin de Courtenay ${ }^{22}$, Otto Jespersen ${ }^{23}$; mimo, że ido miał mało zwolenników, wydano w nim 150 książek (zob. Encyklopedia językoznawstwa..., 1999, s. 245);

${ }^{21}$ Ich podłożem są języki naturalne, w przeciwieństwie do języków apriorycznych, niekorzystających z już istniejących języków naturalnych (zob. Białołus 2018).

${ }^{22}$ Jan Niecisław Ignacy Baudouin de Courtenay - polski językoznawca, uznawany za jednego z najwybitniejszych w historii dyscypliny. Propagował esperanto. Zob. https://www.google.com $/$ search $? \mathrm{q}=\mathrm{J} .+$ Boudouin $+\mathrm{do}+$ Courtenay \&oq $=\mathrm{J} .+$ Boudouin $+\mathrm{do}+$ Courtenay\&aqs $=$ chrome..69i57.1163j0j7\&sourceid=chrome\&ie $=$ UTF-8 $[25.01 .2020]$.

${ }^{23}$ Jens Otto Harry Jespersen - duński językoznawca, filolog angielski i fonetyk. Zajmował się aktywnie dziedziną języków sztucznych, w 1928 r. przedstawił własny projekt języka novial. Zob. https://www.google.com/search?q=Otto+Jespersen\&oq=Otto+Jespersen\&aqs=chrome..69i57j015.2734j0j8\&sourceid=chrome\&ie=UTF-8 [25.01.2020]. 
- interlingua:

1. 1903-1904: język opracowany przez włoskiego matematyka Giuseppe Peano, oparty na uproszczonej łacinie (latino sine flexione); dziś poza astronomią nieużywany;

2. 1951 r.: język opracowany przez niemieckiego lekarza Alexandra Godego, powstał na bazie łaciny i współczesnych języków romańskich; „bywa używany na międzynarodowych zjazdach naukowych, głównie medycznych" (Encyklopedia językoznawstwa ..., 1999, s. 259);

- novial: język oparty na językach romańskich i niemieckim, zbliżony do esperanta; twórcą był Otto Jespersen w latach dwudziestych XX wieku; mało używany (Encyklopedia językoznawstwa ..., 1999, s. 398);

- occidental: bazujący głównie na elementach języków zachodnioeuropejskich, utworzony pod koniec lat dwudziestych XX wieku przez Estończyka Edgara von Vahla; dziś nie ma prawie wcale zwolenników (Encyklopedia językoznawstwa ..., 1999, s. 400);

- volapük (volapik): nazwa jest przekształceniem angielskich słów: world i speak; utworzony w 1879 r. przez niemieckiego księdza Johanna Martina Schleyera, oparty w dużym stopniu na gramatyce i słownictwie angielskim; w jego skład wchodzą także elementy łaciny, niemieckiego, francuskiego (Encyklopedia językoznawstwa..., 1999, s. 627); początkowo cieszył się dużym powodzeniem, potem był stopniowo wypierany przez esperanto; nowe życie zyskał dzięki Internetowi (zob. Białołus 2018).

Tabela 2. Języki sztuczne w ujęciu chronologicznym

\begin{tabular}{|c|c|c|c|}
\hline JEZZYK & TWÓRCA & $\begin{array}{c}\text { CZAS } \\
\text { POWSTANIA }\end{array}$ & $\begin{array}{l}\text { ELEMENTY } \\
\text { SKLADOWE }\end{array}$ \\
\hline volapük & $\begin{array}{c}\text { niemiecki ksiądz } \\
\text { Johann Martin } \\
\text { Schleyer }\end{array}$ & $1879 \mathrm{r}$. & $\begin{array}{c}\text { język angielski oraz łacina, } \\
\text { niemiecki i francuski }\end{array}$ \\
\hline esperanto & $\begin{array}{c}\text { polski lekarz } \\
\text { Ludwik Zamenhoff }\end{array}$ & $1887 \mathrm{r}$. & $\begin{array}{l}\text { głównie języki romańskie } \\
\text { i częściowo germańskie }\end{array}$ \\
\hline $\begin{array}{l}\text { interlingua } 1 \\
\text { (latino sine } \\
\text { flexione) }\end{array}$ & $\begin{array}{l}\text { włoski matematyk } \\
\text { Giuseppe Peano }\end{array}$ & 1903-1904 r. & uproszczona łacina \\
\hline $\begin{array}{c}\text { ido } \\
\text { (esperanto } \\
\text { reformita) }\end{array}$ & $\begin{array}{c}\text { franc. inżynier } \\
\text { Louis de Beaufront, } \\
\text { dr filozofii } \\
\text { Louis Couturat }\end{array}$ & $1907-1908 \mathrm{r}$. & $\begin{array}{c}\text { uproszczona forma } \\
\text { esperanta }\end{array}$ \\
\hline adamitik & $\begin{array}{c}\text { węgierski lekarz } \\
\text { Antal Velics }\end{array}$ & ok. 1909 r. & język węgierski \\
\hline
\end{tabular}


Tabela 2. (cd.)

\begin{tabular}{|c|c|c|c|}
\hline JĘZK & TWÓRCA & $\begin{array}{c}\text { CZAS } \\
\text { POWSTANIA }\end{array}$ & $\begin{array}{c}\text { ELEMENTY } \\
\text { SKLADOWE }\end{array}$ \\
\hline novial & $\begin{array}{c}\text { duński językoznawca } \\
\text { Otto Jespersen }\end{array}$ & ok. $1928 \mathrm{r}$. & $\begin{array}{c}\text { głównie języki romańskie } \\
\text { oraz niemiecki; zbliżony do } \\
\text { esperanta }\end{array}$ \\
\hline occidental & $\begin{array}{c}\text { estoński nauczyciel } \\
\text { Edgar von Vahl }\end{array}$ & $\begin{array}{c}\text { koniec lat } \\
\text { dwudziestych } \\
\text { XX w. }\end{array}$ & $\begin{array}{c}\text { głównie elementy języków } \\
\text { zachodnioeuropejskich }\end{array}$ \\
\hline interlingua 2 & $\begin{array}{c}\text { niemiecki lekarz } \\
\text { Alexandr Gode }\end{array}$ & $1951 \mathrm{r}$. & $\begin{array}{c}\text { łacina i współczesne języki } \\
\text { romańskie }\end{array}$ \\
\hline
\end{tabular}

Źródło: opracowanie własne

Języki powyższe muszą być rozpatrywane w kontekście edukacyjnym w tym sensie, że nie mogą być przyswajane w bezpośredni sposób. Powstały jako sztuczne twory według prawideł oraz opracowanych schematów i należy się ich (na) uczyć, aby móc z nich korzystać.

Największą popularność zdobyły esperanto i interlingua 2 (interlingua Godego). Pierwszy ma dość dużo zwolenników, a liczbę użytkowników szacuje się na około 100000 do około 2000000 (w zależności od poziomu jego opanowania). Ocenia się także, że dla około tysiąca osób jest to używany na co dzień w rodzinie język pierwszy, w którym komunikują się różnojęzyczni rodzice. Jest kodem całkowicie regularnym, bezwyjątkowym, ale mocno zniekształcającym słowa z języków składowych i zawierającym sztucznie stworzone wyrazy. W rezultacie uważa się, że to język dla wtajemniczonych, chociaż w esperanto toczą się debaty konferencyjne ${ }^{24}$, istnieje oryginalna literatura oraz wiele thumaczonych pozycji, są także wydawane gazety i emitowane audycje, a wśród wszystkich dostępnych na Wikipedii wersji językowych, zajmuje 32. pozycję (liczba artykułów w esperanto jest porównywalna $\mathrm{z}$ wpisami w językach bułgarskim, duńskim czy ormiańskim) (zob. Białołus 2018, s. 171).

Interlingua (interlingwa) stanowi syntezę istniejących niezniekształconych słów międzynarodowych. Może „pomóc zrozumieć zarówno strukturę wyrazów obcych występujących w języku ojczystym, jak i słów międzynarodowych w językach zachodnich, nauczanych powszechnie w szkołach" - czytamy we wstępie do podręcznika (Stenström 1997). Według szacunkowych danych IALA (International Auxiliary Language Association) na naukę interlingwy wystarczy 15 dni (szczególnie dla osób znających jeden lub więcej języków romańskich). Znawcy twierdzą, że nawet ci, którzy nie mają zdolności językowych są w stanie ją opanować w ciągu miesiąca. Jest używana w praktyce - zwłaszcza w nauce i technice. Pewna liczba czasopism naukowych (w szczególności medycznych) na Kubie,

${ }^{24}$ Zob. np. http://interl.amu.edu.pl/interlingvistiko/simpozio2017pl.html [25.01.2020]. 
w Danii, w Peru, w USA, w Polsce publikowała regularnie streszczenia w interlingwie (zob. Stenström 1997). Teksty w tym języku mogą być doskonale rozumiane a prima vista przez osoby, które nigdy się go nie uczyły.

Warto by było rozważyć umożliwienie uczniom we wszystkich szkołach (np. jako zajęcia dodatkowe) zapoznanie się z językami esperanto czy interlingua Godego. I jeden, i drugi mógłby przybliżyć młodym ludziom ideę powszechnego komunikowania się wspólnym, ale niczyim (nieprzynależnym do żadnej grupy etnicznej) kodem i wprowadzić ich w świat internacjonalizmów oraz domysłu językowego. To także cenne źródło ogólnej wiedzy na temat języków i asumpt do ich opanowywania (zob. np. Stenström 1997).

\section{JĘZYK MIĘDZYNARODOWY (PONADETNICZNY)}

W roli wszechjęzyka nie sprawdził się żaden ze sztucznych kodów. Nie powstały one spontanicznie i nie rozwijały się naturalnie, nie są nośnikami kultur ani systemów wartości, co pozbawia je życiodajnego zaplecza ${ }^{25}$. Są więc skazane na pasywność, na istnienie ograniczone w czasie i przestrzeni. Choć ich twórcom chodziło o to, aby wspólny środek komunikacji był w miarę prosty, łatwy do opanowania, nie ma (nie było) możliwości jego bezpośredniego nabywania, a to zmniejsza(ło) jego atrakcyjność. Lingua franca w swej pierwotnej postaci, jak wspomniano, jest martwa, a jej zasady ani elementy składowe nie mają punktu stycznego z teraźniejszością. Posługiwanie się tym terminem w znaczeniu: „kod wspólny, ogólnoświatowy, uniwersalny" jest więc swego rodzaju nadużyciem.

Współczesnie określenie lingua franca jest wiązane z angielszczyzną, przy czym zazwyczaj chodzi tu o odmianę amerykańską (rzadziej brytyjską czy australijską), która jest wszechobecna i masowa (co stanowi jednak kryterium społeczno-polityczne, a nie językoznawcze). Skwapliwie wykorzystuje się ją w komunikacji międzyludzkiej, gdyż odznacza się prostotą gramatyki, przejawiającą się śladową fleksją, przy jednoczesnym bogactwie słownictwa ${ }^{26}$ czy immanentną logicznością (zob. Kurcz 2007, s. 459), ale też stoi za nią siła polityczna, ekonomiczna, kulturotwórcza, technologiczna ${ }^{27}$. Stanowi zatem narzędzie porozumiewania się w sferach polityki, nauki, technologii, biznesu, turystyki, rozrywki, sportu. To

${ }^{25}$ Zob. Mycawka (2017). Autorka wypowiada się na temat esperanto, ale można potraktować jej opinię szerzej.

${ }^{26}$ Bogactwo języka angielskiego wynika jego wyjątkowej skłonności do pożyczania w przeszłości wyrazów z innych języków, przede wszystkim z francuskiego, i do tworzenia nowych słów bazujących na łacinie i starożytnej grece (zob. Kurcz 2007, s. 459).

${ }^{27}$ Z USA wywodzą się najnowsze technologie komputerowe, w tym Internet, a dzisiaj „,w epoce społeczeństw informacyjnych narzucanie nowych technologii porozumiewania się społeczeństw jest podstawowym elementem dominacji” (Ożóg 2001, s. 227). 
język konferencji, szkoleń, negocjacji oraz spotkań na różnych płaszczyznach. „Jego powszechność daje wrażenie egalitaryzmu społecznego, gdyż mówią lub starają się nim posługiwać prawie wszyscy (...) niezależnie od stopnia wykształcenia i statusu ekonomicznego" (Lubecka 1999, s. 101, za: Ożóg 2001, s. 228). Bez znajomości angielskiego trudno więc dziś sobie wyobrazić studia czy karierę zawodową, co powoduje „masowe uczenie się tego języka z jednej strony, a z drugiej - reakcje obronne w różnych krajach przed anglicyzacją rodzimych języków i utratą ich dotychczasowego prestiżu" (Kurcz 2007, s. 45728). Przeciwnicy uznawania angielskiego za kod uniwersalny uważają, że osoby, dla których jest to kod natywny, są uprzywilejowane w sferze prywatnej oraz zawodowej, mając przewagę nad innymi np. w kontaktach towarzyskich czy przy staraniach o pracę. Obawiają się ponadto, że pozycja ich języka ulegnie osłabieniu wskutek naporu angielszczyzny.

$\mathrm{Na}$ koniec przywołamy jeszcze dwie odmiany angielszczyzny mające znamiona języka ponadetnicznego: Basic English (o szerokim zasięgu) i Plain English (o węższym zasięgu, w zakresie języków specjalistycznych).

Basic English stworzył w 1930 r. Charles Kay Ogden. Do jego opanowania wystarczy znajomość zaledwie 850 wyrazów (w tym jedynie 18 czasowników). Używa się go do dziś w środowiskach międzynarodowych, kiedy wymagane jest proste i skuteczne porozumiewanie się, a także w szkołach językowych, gdzie słuchacze chcą poznać język jedynie w stopniu komunikatywnym. „Język ten przyjął się głównie w krajach azjatyckich. Nieświadomie posługuje się nim też często wielu Europejczyków, którym wydaje się, że mówią po angielsku" (Soldecka 2012).

Plain language, czyli prosty język, ma na celu „wyeliminowanie zawiłych, długich i niejasnych konstrukcji językowych z tekstów naukowych, prawnych i korporacyjnych" (Luczak 2016, s. 27). W USA i Wielkiej Brytanii problemem tym zajmowano się od połowy XX wieku; w Polsce to jeszcze rzecz nowa, ale cieszy się zainteresowaniem ${ }^{29}$.

Obydwie odmiany są warte rozpowszechniania. Basic English może być solidną podbudową w osiąganiu wyższych stopni zaawansowania lub pełnić rolę poziomu A0 (survival), niezbędnego do powszechnego porozumiewania się różnojęzycznych rozmówców. Plain language (Plain English, Plain Polish ${ }^{30}$ itd.) z kolei powinien stać się obowiązkowym wariantem języków specjalistycznych dla rodzimych i obcych użytkowników języka, zbawiennym w (z)rozumieniu zawiłego tekstu.

${ }^{28} \mathrm{O}$ amerykanizacji w kulturze i języku polskim, zob. Ożóg (2001).

${ }^{29}$ Od 2012 r. w Instytucie Filologii Polskiej Uniwersytetu Wrocławskiego działa Pracownia Prostej Polszczyzny, która zajmuje się badaniem przystępności komunikacji publicznej oraz analizą tekstów tworzonych przez instytucje publiczne i firmy (Łuczak 2016).

${ }^{30}$ Zob. https://www.ibuk.pl/fiszka/166092/jasnopis.html [18.02.2020]. 


\section{PODSUMOWANIE}

Przedstawione (z konieczności - skrótowo) zagadnienia świadczą o złożoności fenomenu mieszanych języków naturalnych i sztucznych, które miały stać się kodami wspólnymi, uniwersalnymi. Tylko niektóre były/są środkiem porozumiewania się dla wąskiej, niejednorodnej językowo grupy społecznej, na określonym obszarze. W sumie są to języki niczyje, nieumocowane w kulturze, ahistoryczne, nierozwijające się, niepełne. Naturalne, jak pidgin i sabir, służą tylko do komunikacji ustnej (języki kreolskie, jako rodzime, są nauczane w szkole także w wersji pisanej), zaś sztuczne - w większości - istnieją jedynie 'na papierze'.

W tekście zwrócono też uwagę na to, aby z namysłem posługiwać się terminami interjęzyk oraz lingua franca. Pierwszy odznacza się dualną naturą, kształtuje się bowiem na płaszczyźnie kognitywnej podczas uczenia się albo naturalnej podczas bezpośredniego nabywania. W wersji edukacyjnej nie jest środkiem komunikacji między osobami uczącymi się języka docelowego, a przypisywana mu rola 'etapu' pośredniego między j.w. a j.d. musi być za każdym razem precyzowana i kontekstualizowana. Jest to kod osobniczy, powinien więc być rozpatrywany przede wszystkim jednostkowo, jako swoiste studium przypadku ${ }^{31}$. Uczący musi być wyczulony na pojawiające się u uczącego się interferencje i możliwe mieszanie kodów, co jest jedną z przyczyn popełniania błędów, a także wykazać czujność, aby szybko zdiagnozować ewentualne zamrażanie kompetencji i starać się temu przeciwdziałać. Wersja naturalna interjęzyka, która tak samo wymaga indywidulanego traktowania i odrębnych analiz, jawi się zaś jako par excellence mieszany język pośredniczący w komunikacji ustnej między osobami różnojęzycznymi.

Lingua franca nie jest synonimem wszechjęzyka, oznacza jedynie, że jakiś kod może taką funkcję pełnić. Innymi słowy, należałoby mówić, że „x” występuje w roli lingua franca, a nie, że nim jest, chociaż i tak o wiele lepsze jest stosowanie terminu mówiącego o jego uniwersalności, ponadetniczności, swoistej globalności, niż posługiwanie się nazwą martwego języka. Ostrożności wymaga również przypisywanie tej funkcji angielszczyźnie - poza pewnymi dziedzinami, jak np. informatyka czy komunikacja lotnicza, gdyż za każdym razem konieczne są uściślenia typu, m.in.: o jaki zasięg chodzi (Europa?), o którym angielskim jest mowa (amerykański?), o jego postać (Basic English?). Jedno jest pewne - nie wolno dążyć do przyznania jakiemukolwiek obcemu kodowi prymatu w komunikacji między rodzimymi użytkownikami języka.

${ }^{31}$ Studium przypadku może również dotyczyć grup - zwłaszcza jednorodnych języków, gdzie pojawia się dużo podobieństw w kompetencji przejściowej. 


\section{BIBLIOGRAFIA}

Arabski J., 1985, O przyswajaniu języka drugiego (obcego), Warszawa.

Arabski J., 2007, Transfer międzyjęzykowy, w: I. Kurcz (red.), Psychologiczne aspekty dwujęzyczności, Gdańsk, s. 341-351.

Białołus M., 2018, Sztuczne języki wobec mediów społecznościowych, „Pogranicze. Studia Społeczne", t. XXXII, s. 168-181; https://repozytorium.uwb.edu.pl/jspui/bitstream/11320/7481/1/Pogranicze_32_2018_M_Bialous_Sztuczne_jezyki.pdf, https://doi.org/ 10.15290/pss.2018.32.11 [25.01.2020].

Borecka V., 2017, Psycholingwistyczne przyczyny fosylizacji w nauce języka angielskiego, „Białostockie Archiwum Językowe", nr 17, s. 13-31.

Boutet J., 1997, Language et societé, Paris.

Chaudenson R., 1989, Créoles et enseignement du français, Paris [non vidi].

Chaudenson R., 1992, Des îles, des hommes, des langues. Essai sur la créolisation linguistique et culturelle, Paris [non vidi].

Deprez Ch., 1994, Les enfants bilingues: langues et familles, Didier, Paris.

Encyklopedia językoznawstwa ogólnego, 1999, Wrocław.

Grosjean F., 1982, Life with Two Languages. An Introduction to Bilingualism, Cambridge.

Hamers J.F., Blanc M., 1983, Bilingualité et bilinguisme, 2eme ed., Bruxelles.

Hlibowicka-Węglarz B., 2013, Portugalskie języki kreolskie w Afryce, Lublin.

Hlibowicka-Węglarz B., 2016, Wielojęzyczność społeczności dawnych portugalskich kolonii w Afry$c e$, ,LingVaria” XI, 1 (21), s. 165-176.

Hlibowicka-Węglarz B., 2017, Pidżyny i inne języki wehikularne, „LingVaria” XII, 1 (23), s. 25-41.

Hornsby M., 2016, Wielojęzyczność i kontakty językowe, w: N. Nau, M. Hornsby, M. Karpiński, K. Klessa, T. Wicherkiewicz, R. Wójtowicz (red.), Języki w niebezpieczeństwie. Księga wiedzy, Poznań, s. 77-90.

Klein W., 1989, L'acquisition de langue étrangère, trad. de Colette Noyou, Paris.

Komorowska H., 1980, Nauczanie gramatyki języka obcego a interferencja, Warszawa.

Kulczycki E., 2011, Założenia filozoficznych języków apriorycznych, w: M. Cieszkowski, J. Szczepaniak (red.), My w wieży Babel. Między przekleństwem a błogosławieństwem, Bydgoszcz, s. 39-49 [non vidi].

Kurcz I., 2007, A może w miejsce dwujęzyczności-język globalny? w: I. Kurcz (red.), Psychologiczne aspekty dwujęzyczności, Gdańsk, s. 457-356.

Lipińska E., 2003, Język ojczysty, język obcy, język drugi. Wstęp do badań dwujęzyczności, Kraków.

Lipińska E., 2019, Język polonijny czy języki polonijne? „Postscriptum Polonistyczne”, nr 2 (24), s. 191-206.

Lipińska E., (w druku), Jeden język, wiele aspektów - o zróżnicowaniu polszczyzny w kraju i zagranica w kontekście jej nauczania, w: A. Seretny, E. Lipińska (red.), Dydaktyka języka polskiego jako nierodzimego: konteksty - dylematy - trendy, Kraków.

Lubecka A., 1999, Wieża Babel „na wspak”. Komunikacja międzyludzka w świecie współczesnym, „Biuletyn Glottodydaktyczny” nr 5, s. 97-112 [non vidi].

Łuczak A., 2016, Idea „plain English” a rozwijanie sprawności zrozumiałego pisania, „Języki Obce w Szkole", nr 3, s. 27-33.

Łuczyński E., Maćkiewicz J., 2002, Językoznawstwo ogólne. Wybrane zagadnienia, Gdańsk.

McArthur T. (red.) 1992. The Oxford companion to English language, Oxford [non vidi].

Mycawka M., 2017, Uniwersalny język nigdy się nie przyjmie, ,Rzeczpospolita”, https://www.rp.pl/ Edukacja/306199920-Uniwersalny-jezyk-nigdy-sie-nie-przyjmie.html [28.02.2020].

Nickel G., 2000, Rola interjęzyka w nauczaniu języków obcych, w: J. Arabski (red.), Metody badań glottodydaktycznych. Materiaty z konferencji, Katowice. 
Ochotna D., 2016, Język polskiej agory wirtualnej - żargon czy pidgin? Próba definicji na podstawie opracowania McArthura (1992), „Scripta Neophilologica Posnaniensia”, t. XVI, s. 85-97.

Ożóg K., 2001, Polszczyzna przełomu XX i XXI wieku. Wybrane zagadnienia, Rzeszów.

Perego P., 1968, Les sabirs, w: A Martinet (red.), Le langage - Encyclopédie de la Pléiade, Paris, s. 597-607 [non vidi].

Pereira D., 2006, Crioulos de base portuguesa, Lisboa [non vidi].

Płóciennik I., Podlawska D. (2008), Słownik wiedzy o języku, Warszawa.

Selinker L., 1972, Interlanguage, „International Review of Applied Linguistics”, nr 10, s. 219-231.

Słownik polonijny ,, Hau ar ju? ”, 2014, zebr. w USA Z.R. Frącz, https://www.slownikpolonijny.com [19.04.2020].

Soldecka N., 2012, 8 najciekawszych sztucznych języków, https://menway.interia.pl/obyczaje/nauka/ news-8-najciekawszych-sztucznych-jezykow,nId,451587 [28.01.2020].

Stenström I., 1997, Interlingua. Instrumento moderne de communication international, Warszawa, https://sites.google.com/site/jezykinterlingua/podrecznik/wstep [28.01.2020].

Szulc A., 1994, Stownik dydaktyki języków obcych, Warszawa.

Warchoł-Schlottmann M., 1994, Próba opisu kompetencji językowej w niemieckim i polskim u Polaków wiemczech - studium socjolingwistyczne, niepublikowana rozprawa doktorska, Kraków.

Żurek A., 2014, Z badań nad interjęzykiem, w: A. Dąbrowska, U. Dobesz (red.), 40 lat wrocławskiej glottodydaktyki polonistycznej. Teoria i praktyka, Wrocław, s. 291-301.

\title{
Netografia
}

http://interl.amu.edu.pl/interlingvistiko/simpozio2017pl.html [25.01.2020].

http://pl.languagesindanger.eu/book-of-knowledge/list-of-languages/ [30.01.2020].

https://www.ibuk.pl/fiszka/166092/jasnopis.html [18.02.2020].

https://www.google.com/search?q=J.+Boudouin+do+Courtenay\&oq=J.+Boudouin +do+Courtenay\&aqs $=$ chrome..69i57.1163j0j7\&sourceid $=$ chrome \&ie $=U$ UTF-8 $[25.01 .2020]$.

https://www.google.com/search?q=Otto+Jespersen\&oq=Otto + Jespersen\&aqs $=$ chrome..69i57j015.2734j0j8\&sourceid $=$ chrome\&ie $=$ UTF-8 [25.01.2020].

\section{Ewa Lipińska}

\section{NOBODY'S OR COMMON? ABOUT NATURAL AND ARTIFICIAL MIXED LANGUAGES}

Keywords: mixed, artificial, natural languages, interlanguage, lingua franca

\begin{abstract}
The aim of this paper is to sort and characterize natural and artificial mixed languages. These are also classified in an educational perspective. The article stressed the fact that natural mixed languages (e.g. pidgin) were not acquired in natural conditions (at home), whereas artificial languages (e.g. volapik) must be learnt at school. Is also discussed interlanguage as a phenomenon present in the process of learning foreign languages, as well as an effect of natural contact of languages. The article reflected on the matter of searching for a universal language, which could be a global means of communication. Furthermore, the essence of lingua franca is explained and the role of English (and its variants Basic English and Plain English) in the contemporary world is emphasized.
\end{abstract}

